Historic, Archive Document

Do not assume content reflects current scientific knowledge, policies, or practices. 



\section{SPRING CATALOGUE}

\section{OF THE}

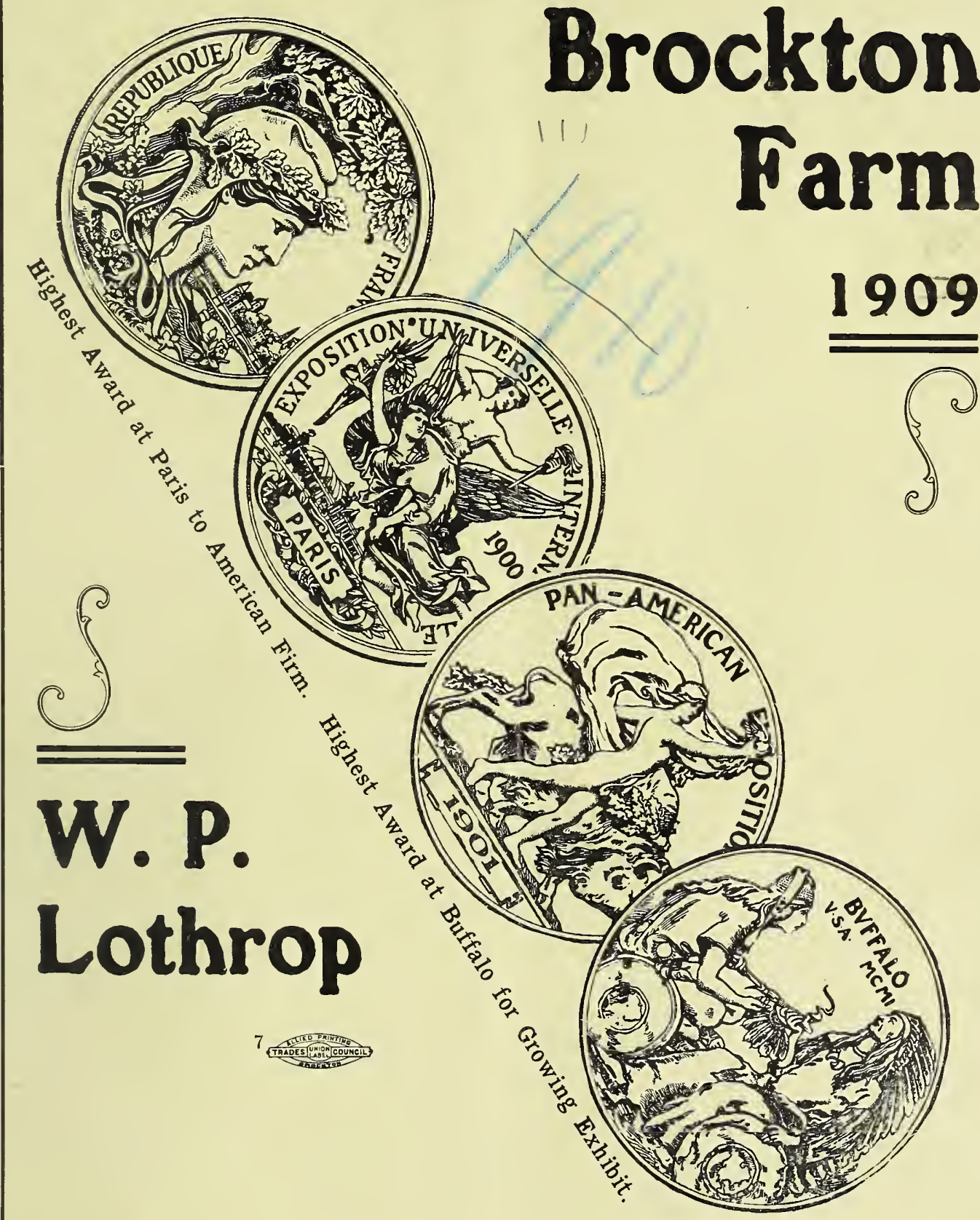

\section{EAST BRIDGEWATER, MASS.}




\section{Classification of Dahlias.}

Dahlias are divided into Show, Fancy, Decorative, Cactus, Pompon and Single.

SHOW DAHLIAS-Include all large, close-flowering varieties of a single color, and those in which the ground color is of a lighter shade than the edges or tips.

FANCY DAHLIAS-Include all striped, large flowering varieties and those in which the ground color is darker than the edges or tips.

CACTUS DAHLIAS-Are known by their long, pointed and twisted petals.

DECORATIVE DAHLIAS-Include all large, loose-flowering varieties.

POMPON DAHLIAS-Include all small flowering varieties. SINGLE DAHLIAS-Have but a single row of petals.

\section{My Business Methods}

I guarantee all tubers to be true to name, and their arrival in good condition. Cash must accompany each order. Goods wanted by mail, add 2c. on the price of each bulb for postage unless otherwise directed. All tubes sent by express at purchasers' expense. 




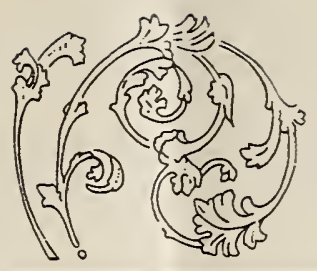

\section{FRIENDS AND PATRONS}

\section{GREETING:-}

I(N presenting my catalogue for the new year, I wish to thank my numerous customers for past favors received from them, and to express $m y$ gratification in the generous amount of orders entrusted to me. I wish to call attention to the fact that my stock consists of strong, fieldgrown roots true to name. I solicit orders with a confidence born of past experience and in continuance of the same assure them that all orders shall, as before, receive prompt and careful attention.

Yours respectfully,

W. P. LOTHROP.

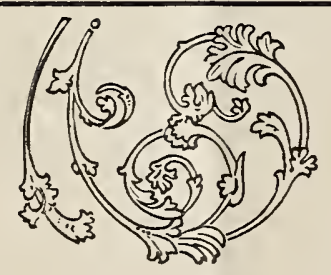




\section{Show and Fancy Dahlias}

New Varieties.

41 Distinction. Blush-white, striped with purple quite distincr. valuable addition, $50 \mathrm{c}$.

63 Acquisition. Deep, rich shade of lilac; a large, beautiful well built flower, borne on very long stems, the finest of its color, 35c.

35 Edmund Boston. Orange, striped with crimson, large flowers, distinct, $35 \mathrm{c}$.

204 T. G. Baker. Yellow, tar superior to any other show dahlia grown, 50 c. (General collection).

Order by No. Price $10 \mathrm{c}$. each, $\$ 1$ per dozen, except where noted (express collect).

404 A. D. Lavoni. Pure Pink

360 Alice Emily. Buff-yellow, perfect form, 15c.

371 Arabella. Primrose, tipped rose.

666 America. Light slate, striped deep crimson, sometimes with solid flowers on same stock, $15 \mathrm{c}$.

945 Annie Moore. A fine variegated flower, color a beautiful combination of cherry, pink and white.

696 Adverture. Blush, striped lake, $25 \mathrm{c}$.

305 Black Dude. Darlk maroon, $15 \mathrm{c}$.

110 Cecil. Pure yellow, 35c.

572 Chorister. Fawn striped primrose and rose, $25 \mathrm{c}$.

707 Chieftain. Purple-lilac, large and full, $25 \mathrm{c}$.

50 Cuban Giant. Crimson, very large, 25c.

222 Duchess of Albany. Pale orange striped rich crimson, 3j̄c.

270 Duke of Edinburg. Yellow.

379 Dr. J. P. Kirtland. Dark velvety crimson, very large.

683 Davis Sport. Purple, tipped lighter.

925 Duke of Fife. Rich cardinal, $15 \mathrm{c}$.

655 Dazzler. Yellow striped scarlet, $25 \mathrm{c}$.

797 David Johnson. Salmon and rose, $25 \mathrm{c}$.

841 Emily. Light ground tinted with lavender, 15c.

378 Emily Edwards. Blush tinted lavender, 25c.

756 Florence Tranter. Blush white edged purple, $25 \mathrm{c}$.

798 Eclipse. Bright organe-scarlet, well built fiower, one of the best, $25 \mathrm{c}$.

133 Fascination. White suffused lavender, large, perfect flowers on long stems, $15 \mathrm{c}$.

564 Frederick Smith. Lilac striped purple, $15 \mathrm{c}$.

54 Falcon. Fawn edged crimson, $25 \mathrm{c}$.

400 Goldspere. Bright red with golden tip. 
Golden Age. Sulphur-yellow.

Gen. Grant. Orange, striped crimson, 20c.

Gold Medal. Canary yellow with fine stripes and splashings of red, 35c.

1036 Globe de Mantes. Bright scarlet, one of the best, 25c.

1047 Gen. Henry. Golden yellow, large and fine, very attractive, 25c.

887 George Barnes, Rich lilac, striped crimson, 25c.

1043 Gaiety. Yellow, striped red, tipped white, 25c.

799 Harbinger. Peach color.

565 Henry Glasscock. Buff striped and spotted crimson, 15c.

704 Harry Keith. Rosy purple, large, 15c.

178 Harrison Weir. Rich clear yellow, 25c.

180 John Walker. Pure white, 20c.

374 James Vick. Dark velvety, purple-maroon, 15c.

948 John Downie. Light yellow, tipped red, 20c.

290 John Bennett. Yellow edged scarlet.

653 John Thorpe. White edged pink, 15c.

316 John Fobes. Fawn striped maroon, 25c.

886 John Cooper. White, striped lake, 25c.

800 James Cocker. Lovely purple, $20 \mathrm{c}$.

55 Jessie McIntosh. Red with white tips, $25 \mathrm{c}$.

1016 Julia Wyatt. Creamy-white, 15c.

705 J. T. West. Yellow, heavily tipped purple, $15 \mathrm{c}$.

403 Keystone. Purplish lilac, striped maroon.

293 Kaiser Wilhelm. Yellow tipped scarlet, $15 \mathrm{c}$.

159 Klondyke. Bright yellow, very fine, $25 \mathrm{c}$.

634 Lucy Fawcett. Light yellow, striped purple.

700 Margaret Bell. Magenta, large and fine.

370 Mrs. Langtry. Cream tipped crimson.

942 Mira. White, with lavender tips.

940 Meteor. Bright red, large, 15c.

409 Mary D. Halleck. Canary yellow.

795 Mrs. Campbell. Pale yellow shaded fawn, 25c.

1011 Miss Alice King. Ivory-white edged with soft rose, 25c.

1033 Mercedes. Rose and white, a very showy flower, 25c.

1035 Mad Furtado. Pure white, very large, 25c.

44 Mrs. Gladstone. Delicate soft pink, $25 \mathrm{c}$.

1039 Mrs. Pierce. Cherry pink and white.

563 Mrs. Kendall. White, heavily rosy purple, $15 \mathrm{c}$.

758 Mabel. Lilac, striped crimson, very large, $25 \mathrm{c}$.

669 Norma. Bright orange-butf, 15c.

805 Nugget. Yellow tipped scarl,et, very large, 35c.

815 Olympia. Deep rose-pink striped and penciled with crim. son, $15 \mathrm{c}$.

965 Prince Bismarck. Pure white shot with purple, 25c. 
377 Penelope (English). Fawn shaded ambed and tinted yellow, very large, $35 \mathrm{c}$.

365 Peri. White tipped lavender.

650 Purple Gem. Purple.

880 Parrot. Yellow striped crimson, fine, $25 \mathrm{c}$.

727 Robert Broomfield. Pure white, long stems.

748 Rebecca. Lilac striped crimson, large, $15 \mathrm{c}$.

1015 Royalty. Pale yellow tinged rosy purple, $15 \mathrm{c}$.

345 Pluton. Yellow, very large and fine, $20 \mathrm{c}$.

120 Sensation. Dark pink, $15 \mathrm{c}$.

113 S. Mortimer. Pale rose, striped crimson, $20 \mathrm{c}$.

625 Statesman. Purplish crimson, 20c.

130 Sunset. Yellow, flaked and striped scarlet, 25c.

627 Souviner. Cream white edged red, $15 \mathrm{c}$.

881 Sailor Prince. Lilac striped purple, 20c.

963 Silvion. A beautiful shade of red.

831 Thomas White. Almost black, $15 \mathrm{c}$.

167 Thomas Goodwin. Dark, almost black, 35c.

845 Virgo Santa. White, $15 \mathrm{c}$.

262 William Wyeth. Crimson-scarlet.

414 William Faucett. Light yellow-tipped crimson.

591 White Swan. Pure white.

807 -William Neats. Reddish fawn, $15 \mathrm{c}$.

586 White Queen. Pure white, 20c.

670 Warrior. Bright scarlet, large, 20c.

\section{Cactus Dahlias}

\section{New Varieties.}

42 Ivanhoe. Bright straw color, a fine variety with long narrow petals, fine form, and large sized flowers, an early blooming variety, 50c.

40 William Marshall. A flower of gigantic dimensions, finest possible form, and petals, and a champion exhibition dahlia. The color is rich orange with bright yellow in the centre, $\$ 1$.

31 Mrs. Stanack Gaskill. Color a delicate and exceedingly beautiful shade of pink. It is of good form, large size, $75 \mathrm{c}$.

34 J. B. Riding. Undoubtedly one of the finest exhibition flowers we have. The petals are very narrow, perfectly incurved, and exceedingly numerous; forming magnificent flowers. Color rich yellow at base shading to deep orange, but decidedly tinged with apricot on outer petals, $75 \mathrm{c}$. 
36 Victorian. This variety is equal to the finest self-colored fiowers in form and petal, but has the additional attraction of belonging to the fancy cactus section. The ground color is pinkish white, freely striped, and speckled with deep crimson, and purple. This variety is a most useful addition for exhibition, $\$ 1$.

38 Mrs. F. Grinsted. A most valuable addition, being a deep rich crimson with just a suspicion of purplish shading. The formation of the bloom is of the finest incurved type. 'The habit is good and no fault will be found with the stem, $75 \mathrm{c}$.

39 Mrs. G. Stevenson. One of the best yellow varieties yet raised. Flowers large with narrow petals arranged star shaped. Very erect habit, $\$ 1$.

43 Mrs. Macmillian. In color one of the loveliest I have ever raised; white in centre, deepening to a beautiful pink at tips. Incurving in form, fine in petal and of great depth. A grand exhibition variety, $\$ 1$.

56 Cockatoo. Ground color, clear yellow, which towards outside of flower assumes a pale fawn tint; every petal being tipped with white, $50 \mathrm{c}$.

\section{General Collection.}

Price 10c. each, $\$ 1$ per dozen, except where noted. Express collect.

947 Albion. Pure white, good, 25c.

782 Alfred Vasey. Reddish amber and pink, 15c.

781 Ajax. Orange suffused salmon and buff, $25 \mathrm{c}$.

596 Arachne. Pure white, with a broad band of bright crinlson, $15 \mathrm{c}$.

924 Alpha. A distinct and new freak of fancy cactus, white ground speckled and striped with purple crimson and lilac, $35 \mathrm{c}$.

855 Amos Perry. Bright scarlet, 25c.

277 Beatrice. Soft rose, $15 \mathrm{c}$.

592 Britannia. Soft salmon pink, $15 \mathrm{c}$.

854 Badenia. Yellow, a fine flower, $15 \mathrm{c}$.

597 Capstan. Soft rose tinted apricot at base of petal, tree bloomer, $15 \mathrm{c}$.

716 Capt Dreyfus. Dark maroon petals, very slender and pointed, $15 \mathrm{c}$.

711 Col. Wilson. Dark scarlet, large, $15 \mathrm{c}$.

658 Charles Woodiridge. Bright crimson, shaded purple, $15 \mathrm{c}$.

783 Countess Lonsdale, Salmon-red, $15 \mathrm{c}$.

835 Cycle. Crimson or carmine, $15 \mathrm{c}$.

839 Cannells Crest. Cherry-red rich in color, long pointed petals, 25 c. 
S61 Columbia. Bright vermillion, the center and tip of each floret white, 25c.

726 Capt Broad. Bright crimson.

901 Crimson King. Crimson-scarlet, $25 \mathrm{c}$.

127 Com et. Silvery rose speckled crimson, $25 \mathrm{c}$.

279 Die Fee. Iight pink with yellow ground, very beautiful, $35 \mathrm{c}$.

393 Edelcactus. A beautiful crimson, $15 \mathrm{c}$.

784 Emperior. Plum color, $15 \mathrm{c}$.

990 Etna. Lilac shaded violet, $15 \mathrm{c}$.

882 Edith Waters. A rosy pink, sport from Loyalty, 15c.

151 Eva. A very fine white, 25c.

856 Fred Cabbold. Clear shining crimson, $15 \mathrm{c}$.

260 Fantasy. Coral color, 15c.

702 Floradora. Wine-crimson, a fine flower, $25 \mathrm{c}$.

770 Favorite. Dark orange, 25c.

983 Florence. Color yellowish orange, $35 \mathrm{c}$.

214 Gloriosa. Scarlet.

827 George Marlowe. Primrose-yellow, shaded amber.

765 Gertrude Symonds. A beautiful shade of lemon-yellow, 15c.

864 Gabriel. Ground color bright crimson, the upper half being snow white, 15c.

984 Gilliard. Crimson-scarlet, $25 \mathrm{c}$.

904 Gen. Buller. Deep crimson shading to white tips, $25 \mathrm{c}$.

987 George Gordon. Yellow shading to qrange-bronze, 35c.

771 Genesta. Amber passing to golden yellow at centre, stems long and stiff, $25 \mathrm{c}$.

821 Goliath. Yellow and salmon, very large, 35c.

903 Hogarth. Dark maroon, 15c.

982 H. F. Robertson. Yellow, 35c.

919 H. E. Wood. Crimson and scarlet, $25 \mathrm{c}$.

116 Harbour Light. Yellow ground, deeply edged ruby-crimson, a bright and effective variety, $35 \mathrm{c}$.

907 imperator. Terra cotta, 15c.

239 lceberg. Ivory white, fine, 25c.

486 John Roach. Buff-yellow, edged sulphur yellow.

202 John Welch. A rich crimson, 15c.

777 J. Weir Fife. Purple.

778 J. W. Wilkinson. Crimson, $15 \mathrm{c}$.

869 J. H. Jackson. Intense blackish maroon, $25 \mathrm{c}$.

1029 Jealousy. Yellow, very fine, 25c.

171 Jewel. Rose carmine, yellow ground, $25 \mathrm{c}$.

51 J. B. Briant. Pale pink, yellow tips, 35c.

734 John Gilpin. Orange and buff, $15 \mathrm{c}$.

629 Keynes White. Ivory-white, $15 \mathrm{c}$.

730 King of Siam. Deep rich purple maroon, $15 \mathrm{c}$.

952 Kriomhilde. Pink and white, very nice, $15 \mathrm{c}$. 
970 Kathleen. Light organge-red, 25c.

594 Laverstock Beauty. Soft vermillion-red.

780 Lord Roberts. White, with creamy center, $25 \mathrm{c}$.

879 Lyric. Bronze red, 15c.

\$76 Lottie Dean. Pale amber-buff, tinted and edged rose, 3əこ.

984 Lovely Ensford. Amber, 25c.

851 Loyalty. Bright coral-red, $15 \mathrm{c}$.

66 Lauretta. Yellow ground, edged with rosy red, large, 35c.

168 Matchless. Crimson.

193 Mrs. Bennett. Light crimson.

602 Mrs. Dickson. Soft rose, clear yellow at base of petal, $15 \mathrm{c}$.

593 Mary Service. Pinlish heliotrope shading to yellowish brown.

787 Mayor Tuppenny. Yellow, and orange fawn, $15 \mathrm{c}$.

789 Mrs. Carter Page. Crimson or maroon-tinged with yellow at base of petal, $15 \mathrm{c}$.

870 M. S. Walsh. Clear yellow, $15 \mathrm{c}$.

974 Mabel Neecis. Orange-scarlet shaded crimson, 2bc.

976 Mrs. Winstanley. Soft scarlet, yellow at base of petal, $15 \mathrm{c}$.

788 Major Weston. Crimson, $15 \mathrm{c}$.

825 Mrs. Freeman Thomas. Clear yellow shading to light orange, towards the tips, $25 \mathrm{c}$.

840 Mabel Tullock. Clear rosy pink, $15 \mathrm{c}$.

863 Mrs. H. J. Jones. Scarlet edged cream, $25 \mathrm{c}$.

866 Mrs. E. Mawley. Clear yellow, $25 \mathrm{c}$.

922 Master Carl. Bright amber, very large, and attractive flower, 50c.

991 Mars. Crimson, $15 \mathrm{c}$.

838 Mary Farnsworth. Yellow tipped white, $15 \mathrm{c}$.

651 Mr. Seagrave: Purplish-rose, 25c.

729 Mrs. J. Harrison. Fine crimson, $20 \mathrm{c}$.

723 Major Hobbs. A very beautiful rose color, $35 \mathrm{c}$.

76 Mrs. De Luca. Golden yellow tipped orange, 35c.

68 Mrs. Daniel Cornish. Yellow with rosy red edges and tips, $35 \mathrm{c}$.

170 Magnificent. Rose salmon, large, $15 \mathrm{c}$.

209 Mrs. J. P. Mace. Blush-pink, 35c.

210 Mr. Keith. Deep blood crimson, 35c.

708 Mrs. Mortimer. Rich terra cotta, $25 \mathrm{c}$.

848 Mrs. Winchester. Coral pink, large, 25c.

1041 Manxman. Orange center with blendings of soft scarlet, shading to purple at tips, $25 \mathrm{c}$.

1045 Mazie Cecil. A beautiful white, 25c.

604 Night. Intense dark maroon, 15c.

902 Nil Desperandum. Orange and red beautifully shaded, very large, $25 \mathrm{c}$.

768 Oliver Twist. Coral-red, $25 \mathrm{c}$. 
60 Osprey. Yellow ground striped light scarlet, 35c.

814 Primrose Dame. Soft primrose yellow.

905 Porcupine. Dark-scarlet maroon.

425 Peace. White, $15 \mathrm{c}$.

701 Prince of Yellow's. Lemon-yellow, very fine, 15c.

989 Prince of Orange. Color dark amber, $25 \mathrm{c}$.

906 Ringdove. Pinkish fawn or dove color, passing to white.

833 Red Rover. Orange-scarlet.

595 Standard Bearer. Firey Scarlet.

822 Strahlein Krone. Deed scarlet.

775 Stella. Vivid crimson, 15c.

377 Sheriff Henderson. Old rose, $25 \mathrm{c}$.

117 Sandpiper. Scarlet shaded orange, 25c.

599 Tillie. Delicate pink.

694 The Clown. Soft brick-red tipped white, $15 \mathrm{c}$.

767 Thuringia. Light orange, large flower, $35 \mathrm{c}$.

764 Thusnelda. Light delicate pink, most refined in form and color, $25 \mathrm{c}$.

910 Uncle Tom. Dark maroon, $15 \mathrm{c}$.

1000 Victor von Sheffel. Delicate pink, very free bloomer, $25 \mathrm{c}$.

1002 Winsome. Pure white, fine flower, 20c.

\section{Decorative Dahlias}

New Varieties.

47 W. W. Rawson. White overlaid amethyst, very large flower, $50 \mathrm{c}$.

45 Papa Charmet. Brilliant.velvety coral-red, very large and tine, $50 \mathrm{c}$.

751 Mad. A. Lumiere. A very attractive Hower, white with violetred points, a fine contrast of colors, $50 \mathrm{c}$.

48 Mme. Victor Vassier. Bright yellow, very free bloomer, the best yellow decorative grown, 50c.

208 Lucy Ferrier. A beautiful rose color, very large attractive flower, 50c.

53 Prof. Mansfield. Variegated red, yellow and white. It is an immense decorative, seven to eight inches across, $35 \mathrm{c}$.

General Collection.

Price 10c. each, \$1. per dozen, except where noted. Express coliect.

102 Beaute Lyonnaise. White edged red, perfect form, 35c.

105 Black Prince. Intense velvety maroon, almost black, perfect form, $15 \mathrm{c}$. 
644 Cora Gleason. Deep purple lake.

750 Catherine Dreer. Crimson-scarlet.

912 Clarebel. Rosy purpie.

913 Centennial. Crinison and maroon.

941 Dolly. Flesh color tipped darker.

580 Duke of Clarence. Crimson-maroon.

149 Grand Duke Alexis. White tinted soft lilac, 15c.

385 Himmilsche. Light purple-lavender, $15 \mathrm{c}$.

389 Juno. A dark maroon, 15c.

761 Julia. Light pink, a very showy flower.

391 Lockenkoff. Light salmon.

503 Lyndhurst. A briliiant scarlet.

819 Lady Holland. White suffused blush edged, bright rose, $15 \mathrm{c}$.

641 Mrs. Winters. Pure white, very large, $15 \mathrm{c}$.

837 Maid of Kent. Cherry-red, crimson ground with white tip.

715 Mrs. C. Turner. Bright yellow, very large.

949 Mrs. Roosevelt. Delicate soft pink, very large, 35c.

853 Mad.Van den Dael. Silvery pink, large, massive flowers, much admired, $35 \mathrm{c}$.

471 Nymphea. Shrimp pink.

762 Nellie. White, very large.

753 Mile. Helene Chervet. A seedling of Mme. Van den Dael, oniy flowers are much larger and florets of enormous width. Color pure white, $35 \mathrm{c}$.

489 Oban. Salmon overlaid crimson-pink.

556 Perle de la tete de Or. Pure white tinted purple, $\mathbf{1 5} \mathrm{c}$.

467 Prince of Orange. Bright orange salmon, shaded apricot.

663 Source de Feu. Deep orange, splashed with vermillion scarlet, large flowers, 35c.

752 Souvenir de Gustave Douzon. A pleasing color of orangered, a giant flower, $25 \mathrm{c}$.

258 William Agnew. Red, very large.

465 William Pierce. White, nice formed flowers.

\section{Pompon Dahlias}

General Collection.

Price 10c. each, \$1. per dozen, except where noted. Express collect.

451 Aillets Imperial. Cream-white, tipped purple.

452 Alewine. Delicate pink, tinted lavender.

728 Ariel. Orange-buff.

30 Amber Queen. Clear amber shading apricot, $15 \mathrm{c}$.

347 Brunette. Crimson, sporting white. 
607 Belle of Springfield. Crimson-scarlet, the smallest danlia grown, 15c.

944 Buff-Yellow. Bright orange.

622 Bricktop. Brick red, long stems, $15 \mathrm{c}$.

735 Capt. Boynton. Maroon, shaded crimson.

936 Clara Harsh. .Cream tipped crimson.

927 Cheerfulness. Old gold, tipped crimson.

939 Cohannette. Lavender, sporting pink.

733 Chrystobell. Yellow, tipped old gold.

108 Cecil. Red tipped white, $15 \mathrm{c}$.

107 Darkness. Dark maroon.

731 Elfin. Primrose-yellow.

574 Fairy Queen. Sulphur yellow, edged pink.

373 Fernleaf Beauty. Cream white, with a margin of crimson.

400 Goldspere. Crimson, tipped gold.

444 Golden Gem. Yellow.

624 Gusta. Purple, small well formed Howers.

479 Gruss am Wein. Crushed strawberry, 15c.

812 Hedwig Polwig. Scarlet and white, $15 \mathrm{c}$.

90 Henretta. Yellow, tipped crimson.

621 Harry. Yellow, lighter tip, long stems, 15 c.

437 lolanthe. Orange, shaded buff, $15 \mathrm{c}$.

613 Little Alan. Rose, fine.

291 Little Bessie. Cream-white.

226 Little Jennie. Primrose yellow.

529 Little Prince. Crimson, tipped white.

620 Leon. Lemon yellow.

616 Maud. Pure white.

83 Minnie. Buff-yellow, tipped pink.

121 Model. Fawn, shaded pink.

396 Nerrissa. Soft rose.

106 Pompomi. Primrose, shading pink.

287 Pure Love. Lilac.

943 Petite Barbara. White, finely quilled.

938 Red Indian. Coral-red.

395 Rosebud. White, edged crimson, $15 \mathrm{c}$.

436 Rosalie. Yellow, edged crimson.

148 Sunbeam. Crimson.

929 Struthers. Pink.

355 Snowclad. White.

454 Sappho. Garnet, sporting pink and white.

431 Virginale. White.

406 Virdifiora (Green Dahlia). Small flowers as green as the foliage and growing in clusters.

605 Yellow Boy. Pure yellow, extra fine.

615 White Beauty. Pure white, the most perfect white pompon grown, $15 \mathrm{c}$. 


\section{Single Dahlias}

General Collection.

Order by No. Price 10c. each, $\$ 1$ per dozen, except where noted. Express collect.

243 Bruce. Pure yellow.

746 Balthsea. Yellow, with crimson stripe, petals pointed.

722 Capt. Marcy. Purple, striped crimson.

749 Clorinda. Brick-red, good.

173 Duke of York. Brilliant scarlet, deeply notched petals.

194 Excelsior. Creamy-white, tipped scarlet.

20 Fedora. Bright yellow.

935 G. E. Varnum. Red, tipped lighter, very large.

240 Guy Mannering. Cream-white, shading yellow.

740 Hubert. White, stained with lilac, striped with deep crimson.

553 Holyoke. Bronze-yellow, very large.

22 Ideal. Yellow, striped crimson.

18 Junita. Pink, tipped and striped darker.

280 Jack Sheppard. Yellow, striped scarlet.

524 John Cowan. Maroon.

229 Kennelworth. Dark crimson.

282 Lady Helen. White with yellow stripes on each petal.

937 Lady Rowena. Sulphur yellow, tipped salmon.

719 Lysander. Crimson, striped maroon.

13 Lord Goff. White, tipped rose, $15 \mathrm{c}$.

19 Lucifer. Soft crimson, very large, $15 \mathrm{c}$.

237 M. C. C. Bright red.

513 Man Friday. Maroon.

743 Miss Burton Pink.

742 Mars. Orange-scarlet.

959 May Kamerly. White, tipped pink, heavily spotted and striped with bright scarlet.

932 Marguerite. Pure white.

717 Phoebe Gilbert. Pink.

718 Phyliis. Bright pink.

946 President Viger. Rich claret color, with a frill of white at centre, 20c.

242 Peveril. Sulphur-yellow.

962 Pauline. Pure white, bordered violet, margined deep glowing crimsoll.

153 Ruth. Deep velvety maroon.

281 Rosebank Cardinal. Scarlet.

25 Therise. Pink and-white.

525 Thomas Beckett. Crimson-lake, with bright yellow rings.

236 The Bride.. White. 
21 Skibo. Yellow, suffused and tipped peach, $15 \mathrm{c}$.

17 Sea Gull. Pure white, with broad petals taping to a point, sometimes flushed pink, $15 \mathrm{c}$.

139 Victoria. Pure white, very large.

997 White Century. Pure white, with heavy, overlapping petals of good texture, $25 \mathrm{c}$.

\section{GLADIOLAS.}

The Gladiolas constitute one of the finest features of the flower garden during the summer and autumn months, for diversity of color and general effect, either in masses or planted in clumps for border decorations. It is also easy of culture, and will thrive, with a liberal supply of manure, in any ordinary garden soil. Early and deep planting is the secret of success.

I have one of the finest collections in mixed colors at 2 jc. per dozen, $\$ 1.50$ per 100 . Express collect.

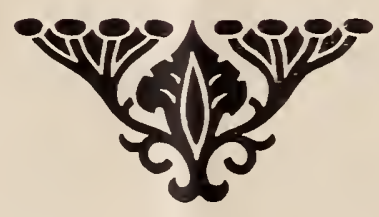






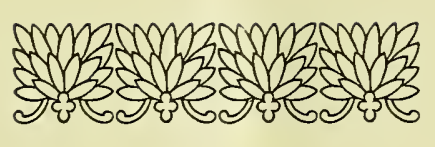

\section{Special Offer.}

In order to obtain new customers and to prove to them that I have what I claim, a strain of Dahlias which are distinctly prize winners, I make the following offer:-

To any one sending $\$ 1.00$ and leaving the selection to me, I will send 20 first-class named varieties, no two alike.

To any one sending $\$ 2.00$ and leaving the selection to me, I will send 40 first-class named varieties, no two alike.

To any one sending $\$ 3.00$ and leaving the selection to me, I will send 62 first-class varieties no two alike.

To any one sending me $\$ 5.00$ and leaving the selection to me, I will send 62 no two alike in all varieties, 100 Gladiolus in a mixture of superior quality, and $1 \mathrm{doz}$. Hardy $\mathrm{Phlox}$ in mixed colors.

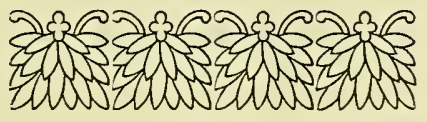




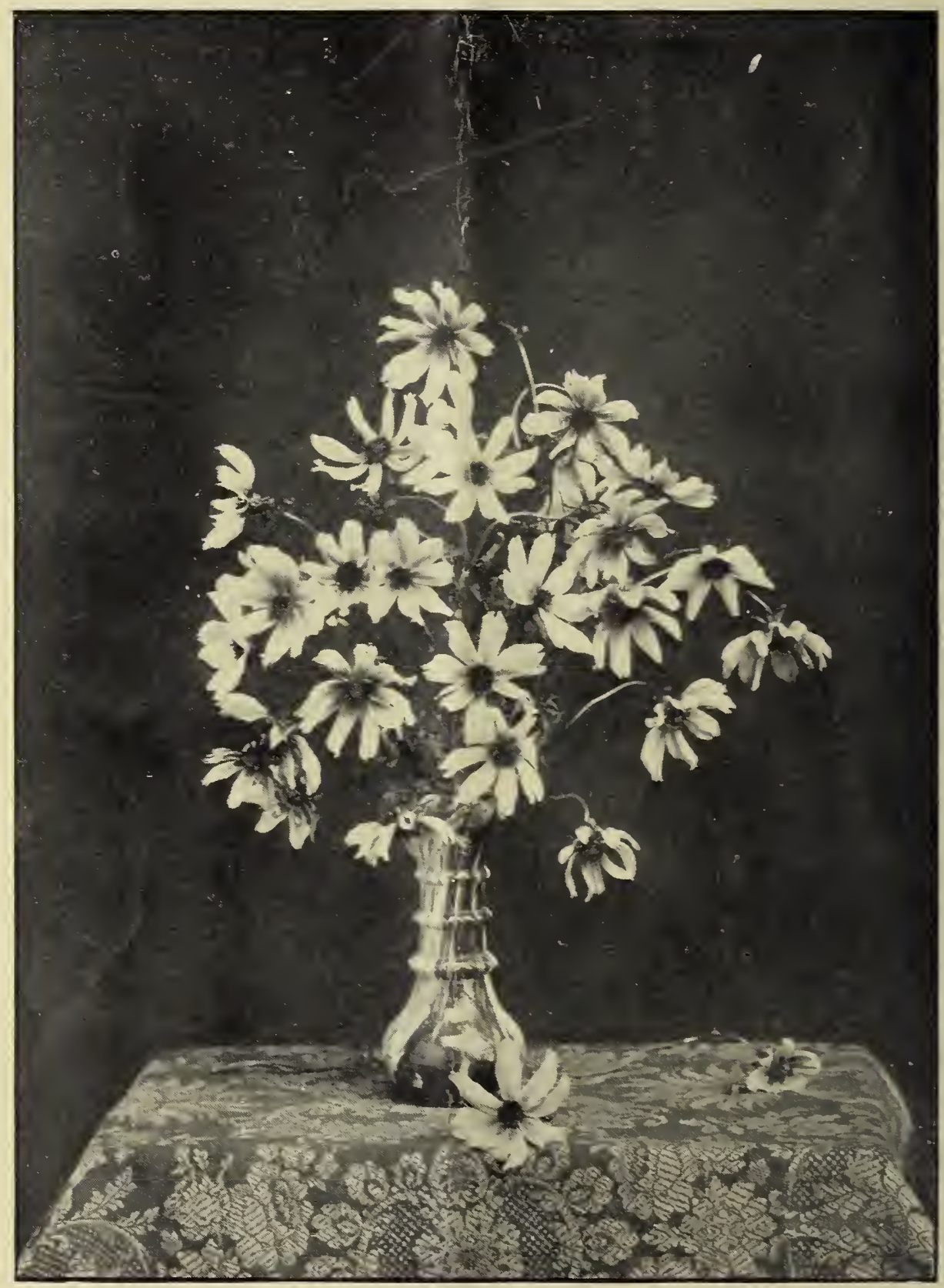

THE SINGLE DAHLIA. 